\title{
A White Horse May or May Not Be a Horse, but Megahistory Is Not Economic History
}

\author{
ALBERT FEUERWERKER \\ University of Michigan
}

To put it directly, in the last section of his essay where Professor Lippit offers his "own understanding of the development of underdevelopment" in China, the author-with the innocence of a first kiss-discovers the gentry and Confucianism. Possibly there are yet some students of modern China to whom it is a novel proposition that the interests of the mainstream of the gentry and the Confucian ideology which protected them were inimical to modern economic development. It is difficult to believe, however, that the weight of that useful proposition is increased merelyand this is all that Lippit adds for his innocent readers-by the wisdom implicit in the words "class" and "relations of production." Except for those incredibly isolated from useful books, these sobriquets can hardly arouse now any sense of new discovery.

Lippit's major criticism of the various theories of underdevelopment, which he considers in the third section of his work before offering his own discovery in the fourth section, is that they are ahistorical, that they do not confront the question of how underdevelopment develops. He encounters, however, both conceptual and-as I shall indicate below-substantive difficulties with the task of showing that underdevelopment was an en- 
dogenous process experienced by the Chinese economy. Having acknowledged that total output expanded and that there is no evidence of any decline in per capita national product between 1400 and the early twentieth century, Lippit proceeds to define underdevelopment in relative terms. "The principal referent for underdevelopment then, in China as elsewhere, is not the decline over time in a country's per capita product, but its per capita product in relation to the rapidly growing per capita products of Western countries from the nineteenth century." But such a "principal referent" only carries meaning "elsewhere" when it can at least be postulated that the growth of the advanced countries has been significantly furthered by their economic exploitation of the less developed ones.

There would immediately have been a further problem if the author had here opted for a paradigm of underdevelopment possibly applicable to relatively small Latin American and Southeast Asian nations, which became heavily dependent on international markets, and attempted to lay the continental mass of China on that Procustean bed. But he avoids such a misstep and correctly. concludes that the economic consequences of imperialism in China were ambiguous. (Imperialism-I have argued this elsewhere-had powerful effects in China's modern history, but undermining the premodern economy was not one of them.) He does resort to a hurried passage, curiously abstract, about the role of "inequality in the relations between China and the West ... in the underdevelopment of China." Since the effects of the foreign economic presence have already been discounted, this "does not mean that the West and Japan took the leading role in creating underdevelopment." Lippit is thus aware of the difficulty of applying the trendy notion "development of underdevelopment" to China once the onus of imperialism has been lightened. He retains, however, enough of a commitment to the concept, whatever the facts for China, for him to borrow Andre Gunder Frank's title and to propose to answer with a single domestic factor the question of why the Chinese economy "developed" from being highly developed (in the Song dynasty, for example) 
to underdevelopment (in the nineteenth and twentieth centuries).

Only he accomplishes nothing of the sort. The fourth section is no more than a static description of the late-Qing gentry in their economic, social, and political roles. The evolution of the Chinese economy from the Song to the Qing is relegated to a few pages (in the first and second sections and a few hints elsewhere) which are as barren of real economic history as this reader has ever seen for paragraphs appearing under such a title as "A Thumbnail Sketch of Chinese Economic History Since 960."

If there is a developmental process suggested at all, it is limited to the almost offhand proposal that the post-Song gentry increasingly incorporated the merchant stratum which during the Song dynasty "still existed as a class distinct from the scholar-officials." The gentry class "developed over the centuries by incorporating within itself all of the separate groups that lived off the surplus created by the direct producers." Perhaps. But Lippit shows no apparent awareness of the by now quite immense literature in Chinese, Japanese, and Western languages which might either support or contradict his suggestion. And, unfortunately, for the nineteenth century - when underdevelopment mainly "developed" -and later, the dominant process with respect to the gentry was quite the opposite of what he proposes. From midcentury onward and with increasing impetus we can discern a differentiation of the gentry, as its sons (and occasionally daughters) took on the roles of import-export merchants, manufacturers, bankers, "modern" intellectuals (teachers, students, journalists, doctors, lawyers, engineers), politicians (reformist bureaucrats, constitutionalists, revolutionaries), and new-style military officers. The main body, the majority, of the gentry retained its conservative attitude-toward economic change and much else. But it was these new social strata who were the dynamic actors at the end of

- the dynasty and the beginning of the republic, and they were no longer crudely opposed to economic development (or even to social change within limits) on the grounds that it might threaten their class interests. It is simply untrue that the probable reinforcement of the power of the lower rural gentry by the centri- 
fugal results of the 1911 revolution was the major reason-it was of course one factor among others-for China's underdevelopment in the twentieth century.

As will now be apparent, what troubles me about this essay is not any serious disagreement with its principal theme, namely, that the class and social structure of Qing China inhibited modern economic growth, while some of the rest of the world (Europe, the United States, Japan) proceeded varying distances along the development road, with the result that China which ranked as a leader, or at least an equal, prior to the Industrial Revolution, and so on, was dumped into the cellar of underdevelopment. What does trouble me-and should discomfort anyone who believes in the value of a deep and genuine understanding of the Chinese experience past and present-is the enormous distance that exists between Professor Lippit's megahistorical approach and the need to come to grips with the complex dynamics of China's economy and society. Sustained consideration of the historical evidence on any economic issue or any event with possibly large implications for the economy is usurped by polemics (admittedly quite mild), random anecdotal history (such as historians themselves seldom perpetrate any more), and the wide-eyed discovery of what is already widely known. Take, for example, the "Thumbnail Sketch" to which I have already referred. It is nearly unbelievable that these pages do not even attempt to summarize the changes that occurred over 900 years in the principal magnitudes and institutions that are the subjects of economic history: output and its sectoral origin, income per capita and its distribution, population and its employment, land and its utilization, capital and its composition (including technology), money and its quantity and circulation, kinds and quantities of "social overhead capital" and services, govêrnment revenue and expenditure, economic theory and policy, and so forth. The remarkable economic expansion of the late seventeenth and eighteenth centuries-about which we now know a great deal even if still not enough, and which would seem to offer the possibility for valuable insights into subsequent stag- 
nation-is passed by in a few lines completely lacking in analytic content.

Precisely this same innocence about China's real economic history informs Lippit's critique of various theories of underdevelopment in the third section. He does indeed make some useful sallies against those who might wish to rely exclusively on any of these six explanations of China's economic backwardness in their most general forms. But the issue of "wrong" or "right" at the level of abstraction at which Lippit remains, although it may have its aficionados, is not the one that should properly occupy the principal attention of any student who desires to go beyond caricaturing Chinese economic history. The experience of onequarter of the human race-if only for its mass-merits genuine historical analysis which penetrates beneath its notorious physiognomy (even the most accurate caricature provides no more) to a systematic, analytic, comparative study of its real anatomy and physiology. What I mean, of course, is that all six of the theories pummeled by Lippit are "wrong" in the sense that accepting any of them as an adequate statement precludes genuine knowledge (which also requires detail and idiosyncracy) because each is so general that it obscures or abandons the valuable insights-at some level of analysis-proffered by the others. But if we accept with equal finality the "theory" offered by Lippit in the fourth section, and rest content with his generalities, we commit the same fault a seventh time. What is challenging in the study of China's economic history is not merely to label the class and social structure of Qing China as obstructive to development, but to demonstrate with as high a degree of verisimilitude as possible the complex processes and institutions by means of which the Confucian elite maintained itself, produced and distributed society's goods and services, and fended off economic and social change.

These are genuine historical problems of the highest order of intellectual importance and moral relevance. But their pursuit requires more than a justifiable sense of outrage at China's fateand less justly at those scholars who are too ignorant or too mis- 
guided to understand simplified Marxism. To outrage must be added useful theory and intimate acquaintance with the prodigious historical sources. The several theories of underdevelopment discussed in the third section, impotent as each is to explain all, do however in some cases suggest the intervening mechanisms (organisms? systems?) by means of which our Confucian elite built and sustained their kind of society for so long. It is through the analysis of such relationships, institutions, and processes at the middle range and lower that we shall be able to link theory and empirical data to achieve a more adequate understanding of China's economic and social history.

I doubt, for example, that "Preindustrial Stage Theory" (which derives from Professor Rostow's "stages of economic growth") was ever a very valuable analytic tool. But it does have the virtue, which Lippit's essay lacks, of acknowledging a distinction between premodern and modern economic growth. There is-I would argue, and Lippit of course disagrees: "the rate of technological progress needed to assure growth in per capita product was indeed quite modest," he asserts without evidence-a qualitative difference between slow and fluctuating growth of output, and so on within a slowly changing ("traditional") technology such as China experienced over the centuries and "modern economic growth" (under capitalism or socialism) as defined by Professor Kuznets. Those conditions which conduced to premodern economic growth from the Song to the Qing may have been precisely the principal obstacles to modern economic development. Thus from the point of view of "modern economic growth," a process which Lippit himself certainly agrees has occurred in China since 1949, "underdevelopment" is a characteristic of all "traditional societies." Indeed it may be the "normal" state of things on the scale of world history, so that the really significant intellectual task is to account for the rapid development of the West and Japan.

The "Vicious Circle of Poverty Thesis" as an explanation of China's underdevelopment errs as Professor Lippit points out in greatly underestimating the savings potential-i.e., the surplus 
above subsistence requirements-of the Chinese economy. Although a surplus in this sense must exist in general for the social system to continue along its traditional path, it is nevertheless possible-indeed inevitable - that at specific times and in definite places both the supply of savings and the demand for investment were inadequate for the purposes of sustaining or increasing output. While conceptually a surplus always exists, in real history the choices, frictions, and accidents of man producing and consuming in a complex society may make Nurske's formulations quite useful tools for detailed historical analysis of real cases. Take, for example, Professor Lippit's estimate of the actual rural surplus in 1933 as equal to $19 \%$ of net domestic product. $\mathrm{He}$ assumes that after deducting the proportion of investment, communal services, and government consumption attributable to the rural surplus (4\% out of a total of $5.8 \%$ of NDP for these purposes in 1933), 15\% of NDP was utilized for luxury consumption by the rural elite, but might potentially have been available for productive investment. Indeed some part of the rural surplus was wasted in luxury consumption, but other parts were hoarded, "invested" in real estate, or reloaned to peasant borrowers. The principal difficulty with assuming a rural surplus above mass consumption equivalent to $15 \%$ of NDP available for redistribution in 1933 is that neither Lippit nor I have any useful quantitative data with which to estimate the importance of these various alternative uses of the surplus. If, for example, net landlord purchases of agricultural land and urban real estate, hoarding of gold and silver, and consumption loans to farmers were large, this in effect involved a "recirculation" of part of the landlords' income to peasant consumption. None of these was a direct burden on consumption in a particular time period, although in the long run, of course, they increased landlord claims to a share of national income. Only the conspicuous consumption of the wealthy, in particular their spending on imported luxuries, thereby depleting the foreign exchange resources which might otherwise have been available for the purchase of capital goods, was an "exhaustive" expenditure, a direct drain on the domestic product. 
The experience of China's agriculture in the first decade of the People's Republic should be evidence enough that while substantial social change may have been a necessary condition for sustained increases in output, it was far from being a sufficient one. Even with the post-1958 increased emphasis on investment in agriculture, China's farm output still lags. The problems of supplying better seed stock, adequate fertilizer and water, optimum cropping patterns, and mechanization at critical points of labor shortage have not been easily met. In sum, the whole experience of the first three-quarters of the twentieth century suggests that only with institutional reorganization and large doses of advanced technological inputs could China's agrarian problem be solved.

This brings me to Dr. Elvin's "High-level Equilibrium Trap." Again, it supposes-correctly-a major qualitative distinction between traditional and modern economic growth, which Professor Lippit explicitly - and incorrectly-denies. An exclusively "technological" analysis of China's failure to industrialize before 1949 is, as I have just stated, as unsatisfactory as sole reliance on a "distributionist" explanation. We need both-and both carefully pursued. In the present context, the high-level equilibrium trap offers us one useful intermediate tool with which to understand precisely how the class and social structure of Qing China actually functioned at particular times and places to obstruct the passage from premodern to modern growth. Merely to state that it did so, because it was in the interest of the Confucian elite to preserve what they had, and to go no further with an elaboration of the actual historical institutions and processes by means of which this conservative goal was supported and implemented is megahistory unredeemed in its fecklessness.

Similar paragraphs might be addressed to the relationship between social structure (including the kinship system of traditional China) and underdevelopment, the effect of imperialism (see Feuerwerker, The Foreign Establishment in China in the Early Twentieth Century), and the role of the Ming and Qing state 
and bureaucracy. But I have consumed enough space for the rather simple point that I set out to make after reading Professor Lippit's "The Development of Underdevelopment in China." Let us undertake substantive studies of China's actual social and economic history which draw on all the theoretical resources that we can muster and are based on full use of the enormous contemporary sources that await sophisticated exploitation. We already know that late-Qing and republican China was "poor" and remained so while Europe, the United States, and Japan developed their economies. And we have long understood that both the bureaucratic and nonbureaucratic elite of this epoch were part of the obstacle to modern economic growth in China. Do we then know enough? Hardly. Deeper knowledge and understanding, which will enhance us both intellectually and morally, require an approach far different-and probably far more difficult - than the one I have treated so unkindly in these pages.

Albert Feuerwerker, Professor of History at the University of Michigan, has published a number of studies on China's modern economic history, most recently Economic Trends in the Republic of China, 1912-1949 (1977). 